\title{
Biomass, Protein Content and Cell Damage in Tanzania Grass Irrigated With Saline Water
}

\author{
Nildo da Silva Dias ${ }^{1}$, Osvaldo Nogueira de Sousa Neto ${ }^{2}$, Francisco Vanies da Silva Sá ${ }^{1}$, \\ Débora Evangelista Façanha de Morais ${ }^{1}$, Bruno Goulart de Azevedo Souza ${ }^{1}$, Cleyton dos Santos Fernandes ${ }^{1}$, \\ Celimari Campos da Silva Junior ${ }^{2}$, Eder Junio Vilar dos Santos ${ }^{1}$, Ytalo Cleyton dos Santos Souza ${ }^{1}$ \\ \& Airlis Mendes de Freitas Junior ${ }^{1}$ \\ ${ }^{1}$ Center of Agrarian Sciences, Univerdidade Federal Rural do Semi-Árido, Mossoró, RN, Brazil \\ ${ }^{2}$ Department of Exact, Technological and Human Sciences, Federal Rural University of the Semi-Arid, Angicos, \\ RN, Brazil \\ Correspondence: Francisco Vanies da Silva Sá, Center of Agrarian Sciences, Univerdidade Federal Rural do \\ Semi-Árido, Mossoró, RN, Brazil. Tel: 55-083-998-619-267. E-mail: vanies_agronomia@hotmail.com
}

Received: August 27, 2018

Accepted: December 20, 2018

Online Published: February 15, 2019

doi:10.5539/jas.v11n3p59

URL: https://doi.org/10.5539/jas.v11n3p59

\begin{abstract}
The scarcity of good water quality in semiarid region, combined with the high cost of pumping, has been the main limiting factor for increasing the irrigated area. The use of saline water for irrigation is a very common in semiarid zones, which can result in the soil salinization if irrigation management is not appropriated. To evaluate the biomass production, biochemical components and water consumption of Tanzania grass (Panicum maximum) irrigated with water salinity $\left(1.5,3.0,4.5\right.$ and $\left.6.0 \mathrm{dS} \mathrm{m}^{-1}\right)$ an experiment in greenhouse was carried out in the Universidade Federal Rural do Semi-Árido, Mossoró, Rio Grande do Norte State, Brazil. The variables dry matter, crude protein, ashes, cellular damage on leaves and consume water in the first and second cut of the grass were analyzed under completely randomized design with five treatments and six replications. Salinity water up to $6.0 \mathrm{dS} \mathrm{m}^{-1}$ can be used for irrigation of Tanzania grass plants, with small yield losses. Increased salinity reduces water consumption and increases the water use efficiency of Tanzania grass. Tanzania grass plants have increased protein content when subjected to saline stress, which is a mechanism of action to osmotic adjustment and allows the reduction of plant leaf damage in the second cycle.
\end{abstract}

Keywords: biomass, physiology, Panicum maximum, water quality

\section{Introduction}

In the agricultural development pole of Rio Grande do Norte, part of the water used for irrigation comes from deep wells, which despite the good quality, presents a high cost to obtaining, making it unviable to use in agriculture. However, there are also open wells in the region of the Jandaíra limestone that, although even having a low cost of obtaining, has a high concentration of salts. In the irrigated crops of this region, due to the low cost it has been common the replacement of non-saline water by brackish water of the shallow wells. The waters of the limestone aquifer present relatively high concentrations of salts, being able to be superior to $3.0 \mathrm{dS} \mathrm{m}^{-1}$ (Sousa et al., 2009), being indispensable investigations on the rational use of these waters, since their inadequate use can salinize the soils (Porto Filho et al., 2011), aggravating the problems of desertification.

Since salinity of irrigation water restricts the production of certain plants, salinity is considered as one of the most important factors of irrigation water (Kim et al., 2016). The effects of salinity on plants can be caused by the difficulties of water absorption, specific ion toxicity and salt interference in the physiological processes (indirect effects), reducing the growth of sensitive plants (De Pascale et al., 2013). However, the effect of salinity depends on several factors, standing out the plant species, the cultivar and the saline composition of the environment; Besides, plant tolerance to salinity is influenced by the stage of growth, time and duration of plant exposure to the salts, environmental condition, substrate type and production system (Cosme et al., 2011; Dias et al., 2011).

In order to obtain economically feasible production with the use of water and soils that apresentaqm risk of salinization, several management practices have been used, among which stands out the use of plants tolerant to 
salinity. Forage plants are considered salinity tolerant and can be used as an alternative to exploit the brackish water of the limestone aquifer, although they suffer reductions in their growth, production and quality of the product when exposed to saline stress conditions (Maia et al., 2015).

Investigations related to tolerance to salinity of crops, despite the great interest involved, are scarce; However, for a rational irrigation management strategy, it is necessary to know the effects of irrigation water salts on the soil and the plant at different stages of development (Melo et al., 2011). These data allow to establish criteria of greater exposure of the plant to the adverse environment and to the need for a good cultural conduction, rationally orienting the irrigation.

In view of the above, it is therefore necessary to conduct research aimed at knowing the production potential of the Tanzania grass irrigated with brackish water, making possible its exploitation in small springs of the Northeast of Brazil. The objective of this work was to evaluate the biomass production, biochemical components and the water consumption of the Tanzania grass under the effect of different levels of salinity of irrigation water.

\section{Material and Methods}

The experiment was carried out in a protected chapel type environment with 3,12 and $16 \mathrm{~m}$ height, length and width, respectively, covered with low density polyethylene film with anti-ultra violet additive and thickness of 150 microns, protected on the sides with black mesh 50\%, belonging to the Departmento de Ciências Ambientais e Tecnológicas (DCAT), of Universidade Federal Rural do Semi-Árido (UFERSA), in Mossoró, RN, situated $5^{\circ} 11^{\prime} \mathrm{S}, 37^{\circ} 20^{\prime} \mathrm{W}$ and 18 masl. Each experimental plot consisted of a plastic vase with a capacity of $12 \mathrm{~L}$. The vases had their bases drilled with a $10 \mathrm{~mm}$ drill, and 10 perforations were made in the perimeter of the lower base. Subsequently they were filled with a $0.02 \mathrm{~m}$ gravel layer, covered with geotextile blanket and soil material from Red-Yellow Latosol from the Campus of UFERSA, resulting in a layer of $0.30 \mathrm{~m}$. The soil was sifted, air-dried before being filled into the vases. The vases were placed on wooden benches suspended $0.80 \mathrm{~m}$ high, $1.50 \mathrm{~m}$ wide, $3.00 \mathrm{~m}$ length, located inside the protected environment.

For the establishment of the experiment, a completely randomized design was used, with five treatments and six replications, totaling 30 plots. The treatments consisted of the application of different levels of salinity of irrigation water, represented by the electrical conductivity (EC), being: $\mathrm{S}_{1}=1.5 ; \mathrm{S}_{2}=3.0 ; \mathrm{S}_{3}=4.5$ and $\mathrm{S}_{4}=6.0$ $\mathrm{dS} \mathrm{m}{ }^{-1}$. Water with electrical conductivity $\left(\mathrm{CE}_{\mathrm{w}}\right)$ of $4.5 \mathrm{dS} \mathrm{m}^{-1}$ was obtained from a deep well, the other levels were obtained by diluting the water $4.5 \mathrm{dS} \mathrm{m}^{-1}$ with local water supply $\left(0.5 \mathrm{dS} \mathrm{m}^{-1}\right)$, or by the addition of $\mathrm{NaCl}$, calibrated by a benchtop conductivity meter with automatic compensation for the temperature of $25^{\circ} \mathrm{C}$. The planting was done by hauling, and when the seedlings reached $5 \mathrm{~cm}$ in height a thinning was done leaving 15 plants per vase. The fertilization of the soil of the experimental units was done according to the chemical analysis of the soil material (Table 1), being applied 75,50 and $40 \mathrm{mg} \mathrm{dcm}^{-3}$ of phosphorus, nitrogen and potassium, respectively, being applied via water of irrigation in six events. Triple superphosphate was used as the source of $\mathrm{P}$, urea as the source of $\mathrm{N}$ and potassium chloride as the source of $\mathrm{K}$.

Table 1. Chemical analysis of the soil used in the experiment

\begin{tabular}{|c|c|c|c|c|c|c|c|c|c|c|c|c|c|c|}
\hline $\mathrm{pH}$ & O.M. & $\mathrm{P}$ & $\mathrm{K}^{+}$ & $\mathrm{Na}^{+}$ & $\mathrm{Ca}^{2+}$ & $\mathrm{Mg}^{2+}$ & $\mathrm{Al}^{3+}$ & $(\mathrm{H}+\mathrm{Al})$ & EB & $\mathrm{t}$ & CEC & $\mathrm{V}$ & $\mathrm{m}$ & ESP \\
\hline (water) & -- \% -- & ----- & $\mathrm{mg} \mathrm{dm}^{-3}$ & -------- & ----- & ------. & $---\cdot$ & $\mathrm{cmol}_{\mathrm{c}} \mathrm{dm}$ & ---- & 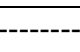 & -------- & --- & --- & 6 \\
\hline$\overline{6.9}$ & 0.70 & 10.1 & 82.2 & 39.7 & 190 & 0.5 & 0 & 0.99 & 2.78 & 2.78 & 3.75 & 74 & 0 & 5 \\
\hline
\end{tabular}

The irrigation management was carried out based on soil moisture data, obtained from tensiometers installed at $0.20 \mathrm{~m}$ depth and a soil water retention characteristic curve determined in the field. A two-day fixed irrigation shift was established, and irrigation depth was determined by tensiometry, with a tensiometer installed at $0.20 \mathrm{~m}$ depth. The applied water volume was calculated from the water retention characteristic curve in the soil and the averages of the tensiometric readings, for each level of salinity.

In order to monitor the microclimate inside the protected environment, five non-aspirated copper psychrometers were installed to read the actual air temperature and relative humidity, recording the averages every thirty minutes and daily averages throughout the environment, that is, temperature in dry bulb and temperature in a moistened cotton gauze, all in the same position in each bench, aiming to measure possible variations in temperature and relative humidity in the plots throughout the day.

The evaluation of the production and biometry of the plants was performed in two consecutive cuts with intervals of 30 days, corresponding to 60 days of accumulated exposure to the brackish waters. The dry matter, 
crude protein, cellular damage, ashes and minerals of Tanzania grass were determined using the methodology described by Silva and Queiroz (2002). Besides, the water consumption of the crop was evaluated for the different treatments studied, being estimated by the sum of the irrigations during the experiment in each vase. Using the dry matter (DM) and water consumption (WC) data of each plant, the water use efficiency of the Tanzania grass plants was determined using the DM/WC ratio, expressed in g of DM per $\mathrm{mm}_{2} \mathrm{O}$.

The evaluated characteristics were submitted to analysis of variance, adopting the scheme of measures repeated in time, using the program SISVAR 5.6 (Ferreira, 2011). The salinity levels and the cuts were compared by means of a polynomial regression equation (linear or quadratic).

\section{Results and Discussion}

There was a significant effect of irrigation water salinity levels and cuts, as well as the interaction between these two factors for all variables (Figures 1, 2, 3, 4, 5 and 6). In the first cut, it was observed that the dry matter of Tanzania grass decreased $1.5 \%$ when compared to the highest $\left(6.0 \mathrm{dS} \mathrm{m}^{-1}\right)$ and the lowest level $\left(1.5 \mathrm{dS} \mathrm{m}^{-1}\right)$ of salinity (Figure 1A), indicating that there was a reduction in the osmotic potential, caused by the increase in the concentration of soluble salts in the soil and, consequently, the reduction of plant growth, which, as an adaptive strategy of the species in the saline environment. The reduction of the phytomass of the plants under conditions of saline stress is due to the decrease of the volume of cells by the reduction of the photosynthesis; such a reduction constitutes a mechanism of adaptation of the cultures to the salinity (Aktas et al., 2006; Savvas et al., 2007). This is due to the increase in the total solutes concentration in the leaf, which contributes to the osmotic adjustment, unless the solutes rise to toxic levels in specific leaf cell compartments.
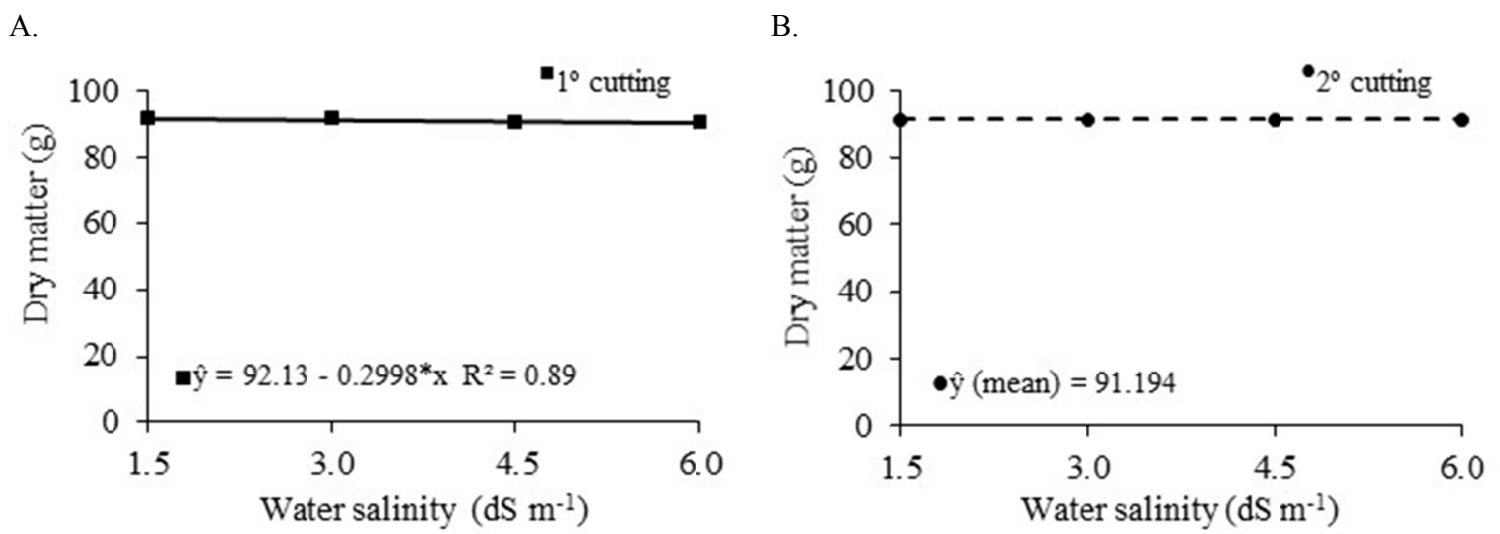

Figure 1. Dry matter for the first (A) and second cut (B) of the Tanzania grass as a function of the irrigation water salinity levels

Note. ${ }^{\text {NS }}$ and $*=$ Not significant and significant at $5 \%(\mathrm{p}<0.05)$ probability.

The literature has observed a decrease in the dry matter of the aerial part of plants under saline stress, in several species, due to the decrease of the osmotic potential, as in the case of melon, studied by Medeiros et al. (2008) and Santos Júnior et al. (2011) in forage species; the reduction of dry matter was also observed in cotton by Oliveira et al. (2008), with increasing levels of soil water stress. However, in the second cut, no influence of irrigation water salinity levels on the dry matter of Tanzania grass was observed, with a mean accumulation of $91.194 \mathrm{~g}$ per plant, indicating that the plant adapted to the saline stress condition in the second cycle (Figure 1B).

Regarding crude protein content, it is possible to verify a linear effect as a function of irrigation water salinity levels for the first cut, with a $1.06 \%$ increase in protein content by $\mathrm{dS} \mathrm{m}^{-1}$ (Figure $2 \mathrm{~A}$ ). In the second cut, the quadratic behavior of the salinity levels was verified, with the maximum protein content being $16.81 \%$ obtained under the level of $3.64 \mathrm{dS} \mathrm{m}^{-1}$ (Figure 2B). According to Viega and Camarão (1994), the crude protein content should be higher than $7 \%$ for the forage plant to maintain the proper functioning of the physiological processes, and also the minimum so that the ruminants have an adequate ruminal fermentation. 
A.

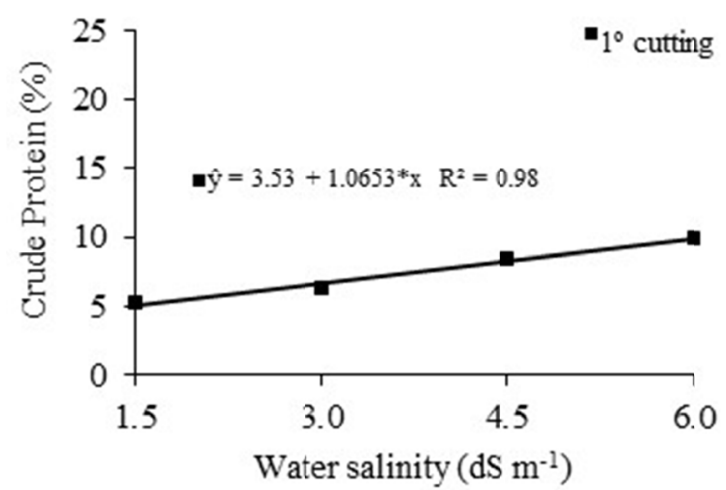

B.

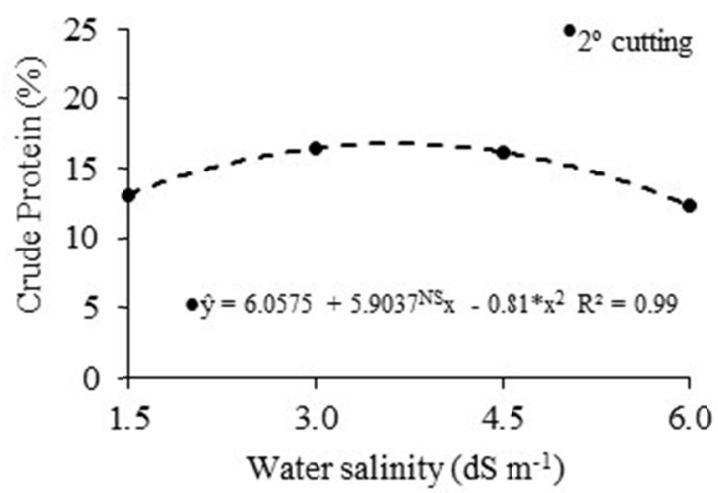

Figure 2. Crude protein content for the first (A) and second cut (B) of Tanzania grass as a function of irrigation water salinity levels

Note. ${ }^{\mathrm{NS}}$ and $*=$ Not significant and significant at $5 \%(\mathrm{p}<0.05)$ probability.

It is noted that in the second cycle, the crude protein contents were higher than $7 \%$ in all salinities tested; while in the first cycle, this limit was reached from the salinity $3.64 \mathrm{dS} \mathrm{m}^{-1}$ (Figure 2B). The excessive accumulation of salts in the soil after successive irrigations with brackish water, causes reductions in the osmotic potential of the soil, consequently reducing the water absorption by the plants. The increase in salinity and the deleterious effects of saline stress promote the expression of a plant tolerance mechanism (Sá et al., 2015), so the increase in crude protein levels observed in Tanzania grass may be related to the osmotic adjustment by biomolecule kinetics, as the basic constituent amino acids of proteins (Taiz \& Zaiger, 2013).

In the first cut, the accumulation of salts in the plant increased linearly with increasing salinity of the irrigation water, with an increase of approximately $15.6 \%$ in the removal of salts in the soil by the Tanzania grass plants of the highest $\mathrm{EC}_{\mathrm{w}}\left(6.0 \mathrm{dS} \mathrm{m} \mathrm{m}^{-1}\right)$ relative to the lowest $\mathrm{EC}_{\mathrm{w}}$ treatment $\left(1.5 \mathrm{dS} \mathrm{m} \mathrm{m}^{-1}\right)$ (Figure $\left.3 \mathrm{~A}\right)$. The greatest accumulation of salts by the leaves of the plants in saline environment occurs due to the formation of special vesicles, formed by vacuolated cells rich in salts, able to promote the regulation of the electrolytic concentrations of the leaves, mainly serving to accumulate $\mathrm{NaCl}$ excess (Taiz \& Zeiger, 2013). In the second cut, no statistical adjustment was observed, observing a mean of $8.65 \mathrm{~g}$ of ash per plant (Figure $3 \mathrm{~B}$ ).

A.

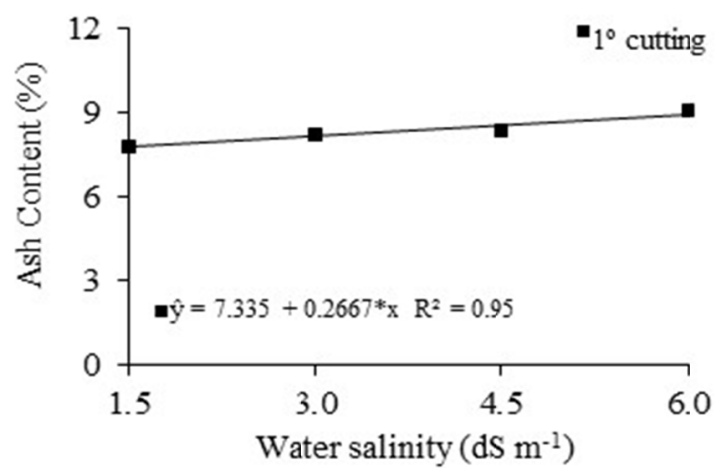

B.

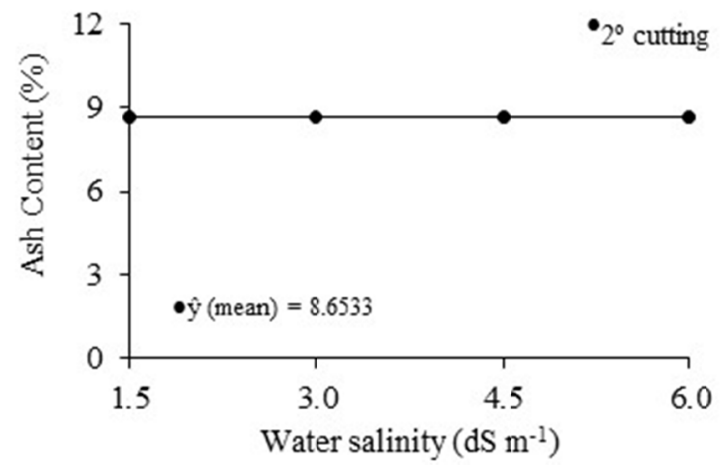

Figure 3. Ash content in the leaves for the first (A) and second cut (B) of Tanzania grass according to the salinity levels for the first and second cut

Note. ${ }^{\mathrm{NS}}$ and $*=$ Not significant and significant at $5 \%(\mathrm{p}<0.05)$ probability.

The evaluation of damage to the integrity of foliar membranes was determined by the evaluation of extravasation of cellular electrolytes. In the first cut, quadratic behavior of the percentage of cell damage as a function of the increase in saline stress was observed, it was observed that the highest damage occurred in the salinity of $3.8 \mathrm{dS}$ $\mathrm{m}^{-1}$, with $7.24 \%$ of damage (Figure 4A). Saline stress, caused by the excess absorption of $\mathrm{Na}^{+}$and $\mathrm{Cl}^{-}$ions, 
promotes ionic disturbance, acting on enzymes and membranes, as well as a disorder of nutritional and hormonal origin (Esteves \& Suzuki, 2008; Muns \& Tester, 2008).
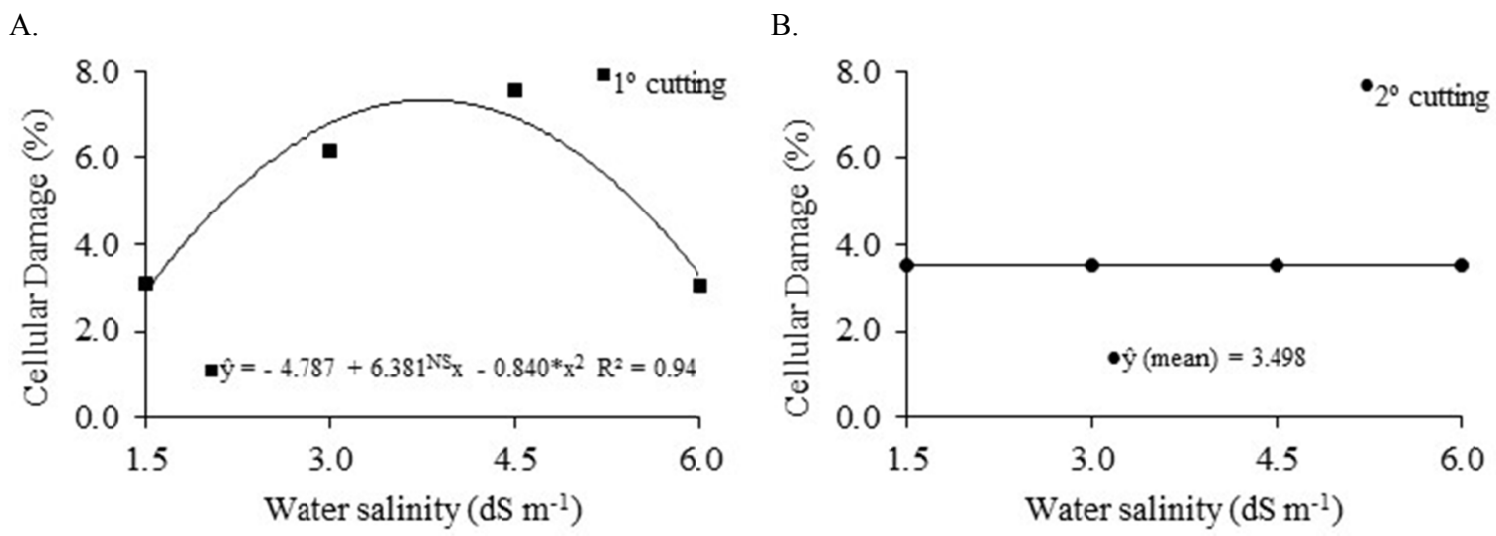

Figure 4. Leaf cellular damage to the first (A) and second cut (B) of Tanzania grass as a function of the salinity levels for the first and second cut

Note. $*=$ significant at $5 \%(\mathrm{p}<0.05)$ of probability and ${ }^{\mathrm{NS}}=$ not significant.

The quadratic response verified in this work is indicative of the osmotic adjustment by the Tanzania grass plants, considering that the reduction of the cellular damages corroborated with the increase of the crude protein content, denoting that the deleterious effects of the saline stress begin to act from the level of $3.8 \mathrm{dS} \mathrm{m}^{-1}$, with consequent expression of the mechanism of tolerance. This can be confirmed by evaluating the second cut, where the salinity did not significantly influenced, finding a mean of 3.5\% damage in the limbs of Tanzania grass leaves (Figure 4B).

Regarding water consumption of the plants, it was observed in the first cut that the use of brackish water in Tanzania grass irrigation interfered with water consumption, with the highest consumption being the lower the salinity level of the irrigation water (Figure 5A). The difference in water consumption between the salinity levels along the cycle is noticeable only after 17 days after planting, with the greatest decrease in water consumption for the highest $\mathrm{ECw}\left(6.0 \mathrm{dS} \mathrm{m}^{-1}\right)$.

A.

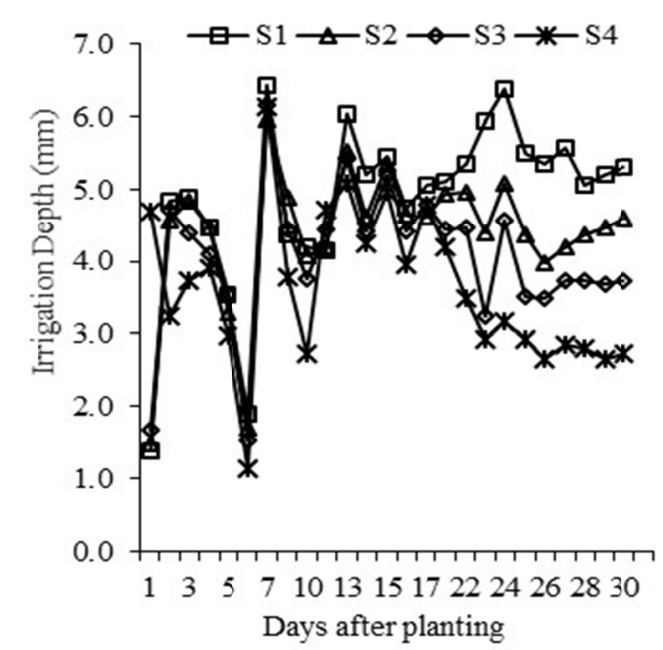

B.

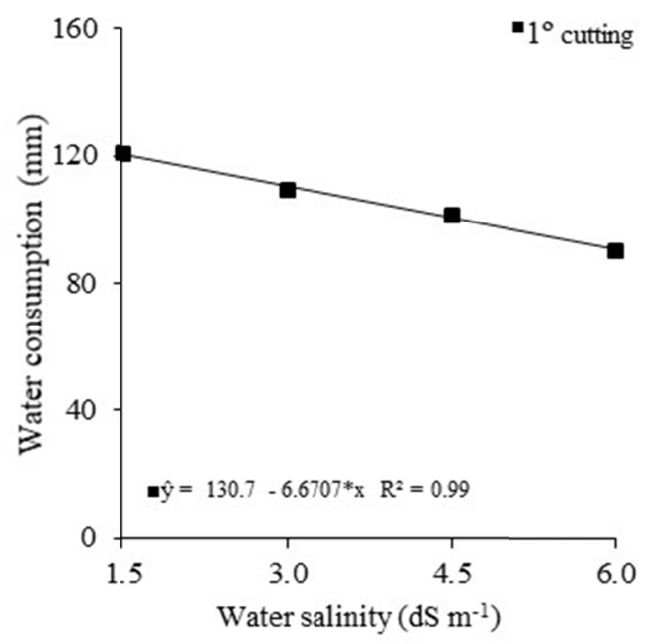

Figure 5. Irrigation depth (A) and water consumption (B) of Tanzania grass according to salinity levels $\left(\mathrm{S}_{1}=1.5\right.$; $\mathrm{S}_{2}=3.0 ; \mathrm{S}_{3}=4.5$ and $\left.\mathrm{S}_{4}=6.0 \mathrm{dS} \mathrm{m}^{-1}\right)$ in $1^{\text {st }}$ cutting

Note. ${ }^{*}=$ significant at $5 \%(\mathrm{p}<0.05)$ of probability and ${ }^{\mathrm{NS}}=$ not significant. 
It is emphasized that the amount of water transpired by the crop at the beginning of the cycle was of the smallest order when compared with the evaporated volume at the soil surface and, besides, the gradual increase of soluble salts in the soil and, consequently, the effect of the (water absorption difficulty), occurred at each irrigation event, increasing the salinity of the root zone in a temporal manner, which is why no appreciable difference in water consumption was observed as a function of the salinity of irrigation water applied in the first days after planting.

Water consumption decreased linearly with increasing salinity of irrigation water (Figure 5B), indicating that there was a reduction of the osmotic potential, caused by the increase of the concentration of soluble salts in the soil, reducing the water absorption by the plant. The decreasing linear effect $\left(\mathrm{R}^{2}=0.99\right)$ observed in the water consumption of Tanzania grass irrigated with brackish water, with a decrease of $5.1 \%$ per dS m $\mathrm{m}^{-1}$, proves that saline stress induces lower water consumption, as a consequence of reduction plant growth.

Regarding the water consumption for the second cut, similar behavior can be verified to the first cut (Figures 6A and $6 \mathrm{~B})$; but the percentage of reduction in water consumption $\left(\mathrm{R}^{2}=0.99\right)$ was lower than in the first cut $(4.62 \%)$, probably due to the accumulation of salts in the soil material throughout the cycle by means of successive irrigations, mainly because there was no fraction of salt leaching. There is a direct relationship between evapotranspiration and growth, that is, evapotranspiration is maximal, and so is growth, when the water requirement of the plant is fully satisfied; Conversely, when there is a water restriction, there is also a reduction of growth, a fact observed in the present study, because the increase of soil salinity reduced the water consumption by plants, from a certain level. According to Dias et al. (2005), in soil when irrigated with brackish water, the osmotic potential is reduced, resulting in a lower water absorption by plants due to the reduction of the total potential of the water in the soil. Thus, when adopting fixed irrigation shifts, a lower variation in soil moisture is expected, which can be monitored by measuring potassium potential since this potential describes the contribution of soil retention forces in the soil.
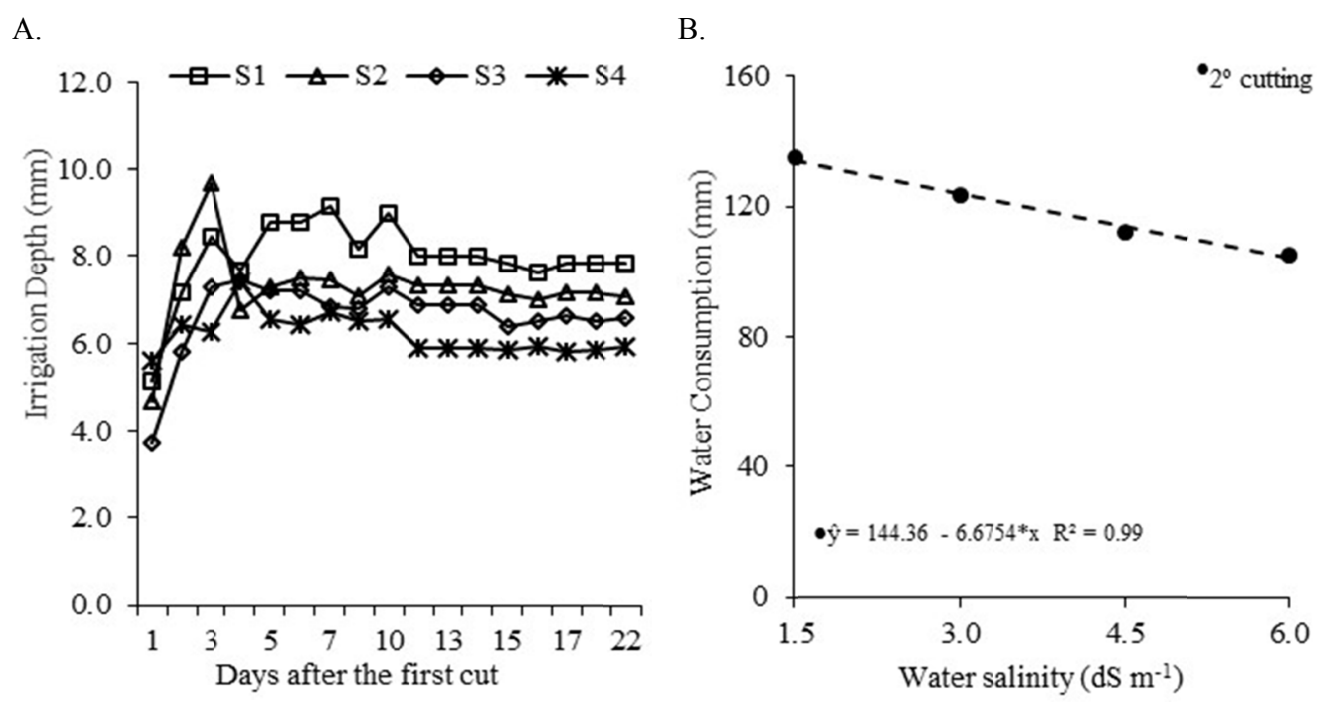

Figure 6. Irrigation depth (A) and water consumption (B) of Tanzania grass according to the salinity levels $\left(\mathrm{S}_{1}=\right.$ $1.5 ; \mathrm{S}_{2}=3.0 ; \mathrm{S}_{3}=4.5$ and $\left.\mathrm{S}_{4}=6.0 \mathrm{dS} \mathrm{m}^{-1}\right)$ in $2^{\text {st }}$ cutting

Note. ${ }^{\text {NS }}$ and $*=$ Not significant and significant at $5 \%(\mathrm{p}<0.05)$ probability.

Regarding water use efficiency, there was an increasing linear behavior of the water use efficiency of Tanzania grass plants as a function of the increase of water salinity in the first and second cuts, with increments of 0.05 and $0.04 \mathrm{~g} \mathrm{DM} \mathrm{mm} \mathrm{H}_{2} \mathrm{O}^{-1}$ for each unit increase in water salinity (Figures 7A and 7B). The reduction of the efficiency of water use in the second cut compared to the first one may be related to the increase of the salinity due to the successive irrigations. Knowing that the efficiency of water use reflects the contribution of the photosynthetic activity (efficiency) in the accumulation of biomass in relation to the water consumption by the plant (Shimazaki et al., 2007). The increase in water use efficiency confirms the expression of a tolerance mechanism by Tanzania grass plants, allowing the plants to become more efficient under stress conditions, however, this efficiency is reduced with progressive increase of salinity over the crop cycles. 


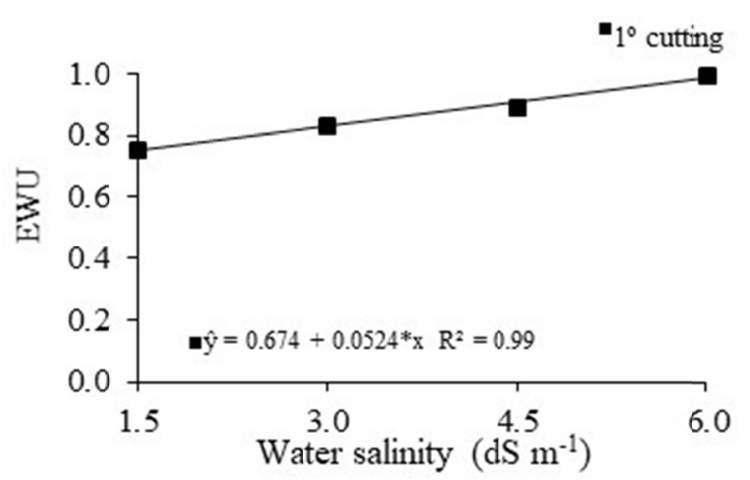

B.

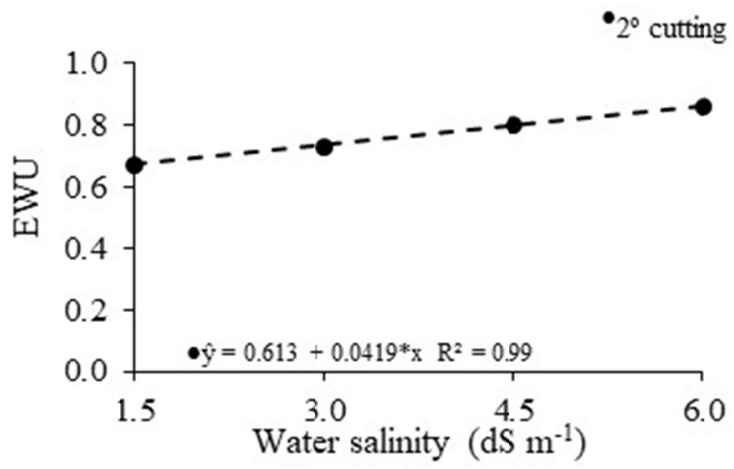

Figura 7. Efficiency of Water Use, (g of DM mm H $\mathrm{O}^{-1}$ ) in the first (A) and second cut (B) of Tanzania grass as a function of salinity levels

Note. ${ }^{\mathrm{NS}}$ and $*=$ Not significant and significant at $5 \%(\mathrm{p}<0.05)$ probability.

\section{Conclusions}

Brackish water up to $6 \mathrm{dS} \mathrm{m}^{-1}$ can be used for irrigation of Tanzania grass plants with small losses in yield.

The increased salinity reduces water consumption and increases the efficiency of water use in Tanzania grass.

Tanzania grass plants have increased protein content when subjected to saline stress, which is a mechanism of action to osmotic adjustment and allows the reduction of plant leaf damage in the second cycle.

\section{References}

Aktas, H., Abak, K., \& Cakmak, I. (2006). Genotypic variation in the response of pepper to salinity. Scientia Horticulturae, 110(3), 260-266. https://doi.org/10.1016/j.scienta.2006.07.017

Cosme, C. R., Dias, N. S., Oliveira, A. M., Oliveira, E. M. M., \& Sousa Neto, O. N. (2011). Hydroponic tomato production using reject of desalination in the nutrient solution applied at different stages. Revista Brasileira de Engenharia Agrícola e Ambiental, 15(5), 499-504. https://doi.org/10.1590/S1415-43662011000500010

De Pascale, S., Orsini, F., \& Pardossi, A. (2013). Irrigation water quality for greenhouse horticulture. Good Agricultural Practices for Greenhouse Vegetable Crops (pp. 169-204). FAO Plant Production and Protection Paper 217. Food and Agriculture Organization of the United Nations, Rome, Italy.

Dias, N. S., Duarte, S. N., Gheyi, H. R., Medeiros, J. F., \& Soares, T. M. (2005). Fertigation management and soil salinity control in a protected ambient using soil solution extractors. Revista Brasileira de Engenharia Agrícola e Ambiental, 9(4), 496-504. https://doi.org/10.1590/S1415-43662005000400009

Dias, N. S., Sousa Neto, O. N., Jales, A. G. O., \& Cosme, C. R. (2011). Response of lettuce cultivars to nutrient solution salinity with saline rejects in hydropony. Revista Brasileira de Engenharia Agricola e Ambiental, 15(10), 991-995. https://doi.org/10.1590/S1415-43662011001000001

Esteves, B. S., \& Suzuki, M. S. (2008). Efeito Da Salinidade Sobre as Plantas. Oecologia Brasiliensis, 12(4), 662-679.

Ferreira, D. F. (2011). Sisvar, a computer statistical analysis system. Ciência e Agrotecnologia, 35(6), 1039-1042. https://doi.org/10.1590/S1413-70542011000600001

Kim, H., Jeong, H., Jeon, J., \& Bae, S. (2016). Effects of irrigation with salinewater on crop growth and yield in greenhouse cultivation. Water, 6(127), 2-9. https://doi.org/10.3390/w8040127

Maia, P. M. E., Dias, N. S., Oliveira, F. A., Oliveira, L. F. C., \& Santos Junior, J. A. (2015). Interaction salinity and nitrogen on yield components of Tanzânia grass. Revista Brasileira de Agricultura Irrigada, 9(4), 259-268. https://doi.org/10.7127/rbai.v9n400330

Medeiros, J. F., Dias, N. S., \& Barros, A. D. (2008). Irrigation management and melon tolerance to the irrigation water salinity. Revista Brasileira de Ciências Agrárias, 3(3), 242-247. https://doi.org/10.5039/agraria. v3i3a264 
Melo, T. K. de, Medeiros, J. F., Espínola Sobrinho, J., Figueirêdo, V. B., Pereira, V. C., \& Campos, M. S. (2011). Evapotranspiração e produção do melão Gália irrigado com água de diferentes salinidades e adubação nitrogenada. Revista Brasileira de Engenharia Agrícola e Ambiental, 15(12), 1235-1242. https://doi.org/ 10.1590/S1415-43662011001200004

Munns, R., \& Tester, M. (2008). Mechanism of salinity tolerance. Annual Review of Plant Biology, 59(6), 651-681. https://doi.org/10.1146/annurev.arplant.59.032607.092911

Oliveira, A. M., Oliveira, A. M. P., Dias, N. S., \& Medeiros, J. F. (2008). Effect of irrigation with saline water on the development of three cotton cultivars. Irriga, 13(4), 467-475. https://doi.org/10.15809/irriga.2008 v13n4p467-475

Porto Filho, F. Q., Medeiros, J. F., Gheyi, H. R., Dias, N. S., Sousa, P. S., \& Dantas, D. C. (2011). Evolution of salinity and $\mathrm{pH}$ of soil cultivated with melon irrigated with brackish water. Revista Brasileira de Engenharia Agrícola e Ambiental, 15(11), 1130-1137. https://doi.org/10.1590/S1415-43662011001100004

Sá, F. V. S., Brito, M. E. B., Silva, L. A., Moreira, R. C. L., Fernandes, P. D., \& Figueiredo, L. C. (2015). Physiology of perception of saline stress in 'Common Sunki' mandarin hybrids under saline hydroponic solution. Comunicata Scientiae, 6(3), 463-470. https://doi.org/10.14295/cs.v6i4.1121

Santos Junior, J. A., Gheyi, H. R., G. Filho, D. H., Dias, N. S., \& Soares, F. A. L. (2011). Sunflower cultivation in a hydroponic system under different salinity levels. Revista Ciência Agronômica, 42(4), 842-849.

Savvas, D., Stamatib, E., Tsirogiannisb, I. L., Mantzosb, N., Barouchasb, P. E, Katsoulasc, N., \& Kittasc, C. (2007). Interactions between salinity and irrigation frequency in greenhouse pepper grown in closed-cycle hydroponic systems. Agricultural Water Management, 91(1), 102-111. https://doi.org/10.1016/j.agwat.2007. 05.001

Shimazaki, K. I., Doi, M., Asmann, S. M., \& Kinoshita, T. (2007). Light regulation of stomatal movement. Annual Review of Plant Biology, 58(1), 219-247. https://doi.org/10.1146/annurev.arplant.57.032905.105434

Silva, D. J., \& Queiroz, A. C. (2002). Análise de alimentos, métodos químicos e biológicos (1st ed., p. 235). Viçosa, Editora UFV.

Sousa, R. B. C., Oliveira, L. M., Carvalho, J. W. C., Dias, N. S., \& Gurgel, M. T. (2009). Seasonal variation of the groundwater for irrigation in Tibau microregion, Rio Grande do Norte state. Revista Caatinga, 22(4), 206-213.

Syvertsen, J. P., \& Garcia-Sanchez, F. (2014). Multiple abiotic stresses occurring with salinity stress in citrus. Environmental and Experimental Botany, 103(6), 128-137. https://doi.org/10.1016/j.envexpbot.2013.09.015

Taiz, L., \& Zeiger, E. (2013). Fisiologia vegetal (5th ed., p. 918). Porto Alegre, Artmed.

Veiga, J. B., \& Camarão, A. P. (1984). Produção forrageira e valor nutritivo de capim-elefante (Pennisetum purpureum, schum) vars. Anão e Cameroon (pp. 1-6, Comunicado Técnico No. 54). EMBRAPA, Brazil.

\section{Copyrights}

Copyright for this article is retained by the author(s), with first publication rights granted to the journal.

This is an open-access article distributed under the terms and conditions of the Creative Commons Attribution license (http://creativecommons.org/licenses/by/4.0/). 